\title{
Evaluation study for the effect of four mango rootstocks on behaviour of Keit mango variety
}

\author{
Zayan, M., Zeerban, S., El Samak, A. \& Ezzat, A. \\ University of kafrelsheikh, faculty of Agricultural Sciences, \\ El-Geish street, Kafrelsheikh 33516 Kafrelsheikh, Egyp, Email: ezzat_eg2003@yahoo.com
}

\begin{abstract}
Summary: Our investigation was carried out in four mango rootstocks were namely Zebda, Socaria, 13/1 an 4/9. This study reviewed the effect of these rootstocks on growth behaviour of Keit mango variety as a scion grown on them. This evaluation and comparison included data on following aspects: the vegetative growth characters, root growth parameter, uptake of some macro nutrient and some organic substance. All results in this regard refer that the Socaria rootstock gave the highest values off all parameters so it is considered as a vigorous rootstocks, means that the trees on this rootstocks will reach to high size after short time. By contrast, Zebda rootstocks gave the lowest values in this concern and this will reflect on tree size on it. This means that the Zebda rootstocks will be useful in the system of high density orchard comparing with Socaria. Concerning to other rootstocks, they were intermediate between Socaria and Zebda rootstocks
\end{abstract}

Key words: Mango rootstocks, Dwarfing mango trees and High density orchard

\section{Introduction}

Mango as a tropical fruit produced in about 90 countries in the world with a production of over 5.1 million tons (Rathor et al., 2007). With the intensification of fruit production due to socio-economic consideration, the role of rootstocks in commercial fruit production has increased considerably in the recent. The rootstocks today have abroad spectrum of uses such as improving fruit quality, imparting adaptability to climatic and edaphic conditions, vigour management, and enhancing fruit yield, etc., especially for temperate fruit crops.

Unfortunately, rootstock selection and uses, as important aspect of modern fruit production, has not made equivalent progress with tropical fruit crops in general and mango in particular.

However, mango is an important national crop in Egypt and major item within the national food basket of the 27 governorates that the area harvested was 82058.4(Feddan) which produced 375461.00 (tones) in 2005. (FAO production year book, 2007)

That we noticed that the average production of mango are generally poor, only about 4.5 ton/feddan because the trees is huge and planted at wide spacing based on eventual tree size, there are not specific rootstock recommendations for commercial mango cultivars, and so seed propagation is still the chief method of multiplication of rootstock. Use of non-descriptive mango stones for multiplication of rootstocks has led to enormous variation in trees in orchards. The use of seedling of unknown pedigree as rootstocks, often from natural cross pollination, poses the threat of possible clonal degradation of superior cultivars in addition to the drawback of non- uniform crop stands and large trees size.

Such large trees mean fewer trees per fedan, difficult pest and disease management, cumbersome harvesting and fruit handing and ultimately poor productivity. Kurian et al. (1996). So that several attempts have already been made to reduce plant height by the use of dwarfing rootstocks in high density planting system which have several advantages such as facility of harvest and fungicides spraying as well as the reduction of fruit loss at post harvest stage. The purpose of this study was to evaluate four mango rootstock namely, Zebda, Socaria, Hybrid 13/1, and Hybrid 4/9 as a main mango rootstock in Egypt in recent, and compared between their effects on Keit mango variety as grafted on them, to have some information about these rootstocks to can us to give good recommendations concept any of these rootstocks can recommended in case of drought or salinity condition, highly orchard density system, and any of it expect to give high production

\section{Materials and methods}

The present work was carried out during 2006 and 2007 seasons at the experimental Farm of faculty of Agriculture of Kafr El-Sheikh University, Egypt. On one, half year old seedlings of Keit mango variety which grafting on the tested rootstocks to study the growth behaviour of this variety on tested rootstocks.

The tested rootstocks were namely Zebda, Socaria, 13-1 and 4-9 rootstocks. The experiment of seedlings was planted 
in 28, Feb., 2006, in containers. In this respect, considered each keit tree grown on each rootstock as a treatment in complete randomized design and each treatment contained five replicates, each replicate contained three plants. Thus the field experiment included 60 seedlings (4 treatment $\times 5$ replicates $x 3$ plant). The planting siol was maxture between Clay, Sand and Organic matter by percent $2: 2: 1$

To evaluation the growth of scions as affected by rootstocks used some measurements as follow:

\section{1- Vegetative growth parameters:}

I Tree vigour: Plant height $(\mathrm{m})$, Trunk diameter $(\mathrm{cm})$

2 Shoots parameters: Number of shoots per plant was recorded at the end of Oct. of each season and Shoots length $(\mathrm{cm})$ was measured at the end of Oct. of each season, and the total shoot growth per plant (m/plant) was calculated from formula: average shoots length per plant $\mathrm{x}$ number of shoots per plant.

3 Leaf characters: Number of leaves per plant, average leaf area $\left(\mathrm{cm}^{2}\right)$ and total leaf area per plant $\left(\mathrm{cm}^{2}\right)$ was calculated from formula (average leaf area X no. of leaf per plant).

\section{II- Root system measurements:}

At the end of the experiment (26, october, 2007) 3 plants from each treatment were carefully removed from containers then root length as the longest vertical root per plant was measured $(\mathrm{cm})$, longest horizontal root $(\mathrm{cm})$, total number of fibrous root was accounted, and fresh and dry weight of root system were measured.

\section{III- Determination of macro nutrients:}

In end of October, 20 mature mid shoot leaves per tree oven dried at 70c and used for determination leaves nutrient status. Dried leaf were ground and digested with sulphoric acid and hydrogen peroxide according to (Evenhuis and Dewaard, 1980). The digested solution was used for determination of $\mathrm{N}, \mathrm{P}$, and $\mathrm{K}$.

Total nitrogen was determined by the micro kjeldahl method (prgel, 1945).

Phosphorus content was determined colormetrcally using aspectrophotometer $882 \mathrm{UV}$ according to method described by (Murphy and Riely, 1962).

Potassium and sodium content were determined by flamphotometer E.E.L model (Jackson, 1955).

\section{IV- determination of some organic substances:}

a- Leaf total carbohydrates:

For carbohydrate determination $0.5 \mathrm{~g}$ fine powder of leaf sample were used with sulphoric acid (30\%) then boiled for 6 hours.Then filtered and diluted to volume. Total carbohydrate content was determined as percent on dry weight by using phenol sulphoric acid method according to Dubois et al. (1956). b- Leaf total phenolic content:

$0.5 \mathrm{~g}$ fine powder of dried leaves was used by adding $25 \mathrm{ml}$ of boiling ethanol $(80 \%)$, and boiled for 10 minutes then cooling and filtered through whatman \#2 filter paper, Then 0.5 $\mathrm{ml}$ folin reagent plus $10 \mathrm{ml}$ solution of sodium carbonat were added.The extract was kept for an hour at room temperature (20c), before using spectrophotometer at $725 \mathrm{~nm}$ to determine color intensity according to Sitaramaiih and Pathak (1979). Total phenols was calculated from a standard curve, and expressed as (mg tanic acid per $100 \mathrm{~g}$ dry weight of leaves).

\section{Result and discussion}

\section{1- Evaluation of vegetative growth behaviour:}

the data in table (1) and photo (1) on vegetative growth indicate the superiority of Socaria as vigorous rootstock which in turn, significantly influenced the vegetative growth of the Keit mango grafted on it, it is clear that Keit mango variety grown on Socaria rootstock exhibited the most vigorous growth, characterized by longer tree height, larger stem diameter, higher number of shoots and larger leaf area per plant than the other tested rootstocks under conditions of this experiment.

On the other hand, zebda exhibited a dwarfing effect on keit variety grafted on it. Other rootstocks such as 4/9 and 13/1 showed intermediate growth coming between socaria and zebda rootstocks. The vigorous growth of Socaria rootstock could be attributed to itslarger root system as shown in table (2) which in turn able to uptake adequate amount of water and mineral nutrients via the roots. Also, the mineral uptake of some macro nutrients results shown in table (3) provide the higher ability of Socaria roots rootstock to uptake more nutrients than those of other tested rootstocks. The rootstocks have significantly effects on scion growth, and the vigorous rootstocks gave the highest number of shoots and leaves, with larger tree size (Reddy et al., 2002 and Duran-zuazo, 2006). In this concern, the vigorous mechanism may be due to higher concentration of some growth promoter as Cytocinin which found with high concentration in trees grafted on vigorous rootstocks (Kojima et al., 1995), also the vigorous growth of some mongo rootstocks associated with high levels of growth promoter as Cytocinin, low level of growth inhibitors as ABA and high sap yield (Murti et al., 2000). The same trend was noticed when studied the dwarfing effect of Pacloputrazol on growth of mango trees (Marti et al. 2001).Also, this mechanism could be explained by Phloem to Xylem ratio, as the low vigour of the tree was associated with a higher primary phloem to primary xylem ratio (Kurian and Lyen, 1992).

\section{2- Evaluation of root growth of four mango rootstocks.}

Data in table (2) and photo (2) gives a good idea of rooting density and distribution. It is clear that socaria rootstock has a vigorous effect through its root system size 
which seemed larger than that of zebda rootstock according to all parameters. 13-1 and 4/9 rootstocks come in between. and vice versa for Zebda one. Conclusively, as all root growth parameters measures could be descendingly arrange the four tested rootstocks as follow: Socaria, 4/9, 13/1 and finally Zebda rootstocks.

In this concern, it could be concluded that good root density and distribution of Socaria rootstock may be due to its vigorous vegetative growth as shown in tables (1) and photos (1) which associated with larger leaf area per plant and consequently with higher amount of organic photosynthetic products in leaves which transport to roots to build new roots with good root system.

In this concern, Hassan (1994) obtained herein results are in agreement with our results that the dwarfing citrus rootstocks had shorter stature, small number of secondary roots and low dry weight.

Also, these result are in line with those reported by ( $E l$ Sayed, 2003a and Ennab, 2003), they found that the most vigorous citrus rootstocks had the highest values of dry weight, number of fibrous roots and root length . Also, Nada et al. (2002) reported that most vigorious citrus rootstocks had the highest top/root ratio.

\section{3- Leaf macro nutrients of the four tested rootstocks}

As for $\mathrm{N}$ and $\mathrm{k}$ content data in table (3) showed the highest percentages in leaves of the keit on Socaria rootstock with significant differences between it and other tested rootstocks in both seasons, followed by keit on 4/9 and 13/1 rootstocks which gave intermediate values in this respect, and the differences between these two rootstocks were not significant in both seasons. Meanwhile the least values of $\mathrm{N}$ in leaves were detected for Zebda rootstock, and the differences were significant when compared with all tested rootstocks.

Regarding, $\mathrm{P}$ content, the values of $\mathrm{P}$ percentages showed similar trend to that recorded for $\mathrm{N}$ and $\mathrm{K}$ level in the leaves of keit variety grown on four tested rootstocks. Accordingly, the same arrangement was true in both seasons but without segnificant differences.

Apparently, the higher levels of N, P and K in leaves of Socaria rootstock may be due to its vigorous growth as shown in table 1 which demand more of these macro elements to encourage building of new vegetative growth. Also, this vigorous rootstock have been are characterized by larger root system and greater number of fibrous roots as shown in table (2) than Zebda as dwarfing rootstock and other tested rootstocks (4/9 and 13/1) as intermediate ones.

in this respect, larger root system size of Socaria rootstock could explain the higher levels of these macro elements in leaves of keit grafted on it.These conclusion find support in the result of Reddy et al. (2002) they found that Vellikulamban as dwarfing mango rootstock showed the lowest $\mathrm{N}, \mathrm{K}$ and $\mathrm{Ca}$ content. Olour as vigorous mango rootstock had the higest leaf nutrient content., Also, the leaf nutrient status of Alphnso on vigorous rootstock were highly significantly for $\mathrm{N}, \mathrm{K}, \mathrm{Fe}, \mathrm{Ca}, \mathrm{Mn}$ and $\mathrm{Cu}$ while levels of $\mathrm{P}$ were not significant affected(Kurian et al., 1996). the vigorious mango rootstocks had highly significant levels for N, k, Ca and mg (Reddy et al., 2002 and Duran-Zuazu, 2006).

\section{4- Leaf analysis of some organic substance}

a- Leaf total carbohydrates\%:

Data in table (4) show that total carbohydrates (\%) in leaves of the keit on Zebda rootstock gave the highest significant values comparing with other tested rootstocks in both seasons. On the other hand, the least values in this respect were obtained in leaves of keit grown on Socaria and 4/9 rootstocks, respectively in both seasons. Meanwhile, the seedlings of 13/1 mango rootstock recorded intermediate values of total carbohydrates in both season.

Conclusively, the most vigorous rootstocks Socaria is characterized by lower total carbohydrates content, this depletion in carbohydrate may be due to its consumption in building new cells, shoots, leaves and other vegetative organs. This conclusion find support in the data of vegetative growth and roots parameters as shown in tables (1and 2). contrarly, Zebda rootstock is characterized by higher level of total carbohydrates, this may be related to carbohydrate accumulation during the less active vegetative growth due to the dwarfing effect of this rootstocks. This conclusion agree with those obtained by Azab (1995) and El-Sayed (2003a) on some citrus rootstocks.

\section{e- total phenol content:}

Data concerning total phenol content as shown in table (4), show that the highest values in both seasons belonged to leaves of keit on Zebda rootstock, and the differences between it and other tested rootstocks were significant in both seasons. Followed in decreasing order by 13/1 rootstock, Then came 4/9 rootstock, and finally Socaria rootstock and the differences between them were significant. It is clear that, the least values of phenols content were obtained from Socaria rootstock which considered vigorious rootstock as shown in tables (1and 2). In contrast, the highest values of total phenolic compound obtained from Zebda rootstock which considered dwarfing rootstock.

Accordingly, it can be concluded that there are a negative relation between phenol content and growth vigour as shown in figs. (1and 2). This conclusion found support in the finding of Murti and Uperti (2003) they found a relation between tree vigour and total phenol in mango leaves. Also, Kriuan et al. (1996) reached the same conclusion on eight mango rootstocks.

So, increasing total phenols content in leaves caused an increase in ABA level in plant tissue leading to arise plant protection against some environmental stresses as concluded by Khattab et al. (2001) on citrus rootstocks 
Table 1. Plant height (m), stem diameter (cm), number of shoot per plant, average shoot length, number of leaves per plant and area per leaf of Keit mango variety as affected by grafting on the four mango rootstocks in 2006 and 2007.

\begin{tabular}{|c|c|c|c|c|c|c|}
\hline $\begin{array}{c}\text { Root- } \\
\text { stocks }\end{array}$ & $\begin{array}{c}\text { Plant } \\
\text { height } \\
\mathbf{m}\end{array}$ & $\begin{array}{c}\text { Trunk } \\
\text { dia- } \\
\text { meter } \\
(\mathbf{c m})\end{array}$ & $\begin{array}{c}\text { No. } \\
\text { shoot } \\
\text { per } \\
\text { plant }\end{array}$ & $\begin{array}{c}\text { Shoot } \\
\text { length } \\
(\mathbf{c m})\end{array}$ & $\begin{array}{c}\text { No. } \\
\text { leaves } \\
\text { per } \\
\text { plant }\end{array}$ & $\begin{array}{c}\text { Total } \\
\text { leaf } \\
\text { area } \\
\text { per } \\
\text { plant } \\
\left(\mathbf{m}^{2}\right)\end{array}$ \\
\hline Zebda & $0.48 \mathrm{c}$ & $0.576 \mathrm{c}$ & $1.91 \mathrm{c}$ & $11.92 \mathrm{c}$ & $49 \mathrm{~d}$ & $0.246 \mathrm{~d}$ \\
\hline Socaria & $0.79 \mathrm{a}$ & $0.928 \mathrm{a}$ & $4.12 \mathrm{a}$ & $17.04 \mathrm{a}$ & $86 \mathrm{a}$ & $0.505 \mathrm{a}$ \\
\hline $13-1$ & $0.64 \mathrm{~b}$ & $0.762 \mathrm{~b}$ & $3.27 \mathrm{~b}$ & $14.29 \mathrm{~b}$ & $60 \mathrm{c}$ & $0.298 \mathrm{c}$ \\
\hline $4 / 9$ & $0.72 \mathrm{ab}$ & $0.782 \mathrm{~b}$ & $2.11 \mathrm{c}$ & $14.28 \mathrm{~b}$ & $80 \mathrm{~b}$ & $0.458 \mathrm{~b}$ \\
\hline \multicolumn{7}{|c|}{2006} \\
\hline Zebda & $0.81 \mathrm{c}$ & $0.998 \mathrm{c}$ & $2.56 \mathrm{c}$ & $12.90 \mathrm{c}$ & $69 \mathrm{c}$ & $0.351 \mathrm{~d}$ \\
\hline Socaria & $1.20 \mathrm{a}$ & $1.838 \mathrm{a}$ & $6.21 \mathrm{a}$ & $17.20 \mathrm{a}$ & $97 \mathrm{a}$ & $0.574 \mathrm{a}$ \\
\hline $13-1$ & $0.95 \mathrm{~b}$ & $1.202 \mathrm{~b}$ & $5.38 \mathrm{~b}$ & $15.21 \mathrm{~b}$ & $72 \mathrm{~b}$ & $0.399 \mathrm{c}$ \\
\hline $4 / 9$ & $1.10 \mathrm{~b}$ & $1.302 \mathrm{~b}$ & $2.92 \mathrm{c}$ & $13.20 \mathrm{c}$ & $85 \mathrm{c}$ & $0.491 \mathrm{~b}$ \\
\hline
\end{tabular}

In Columns, the numbers which are followed by different characters means that there are significant differences

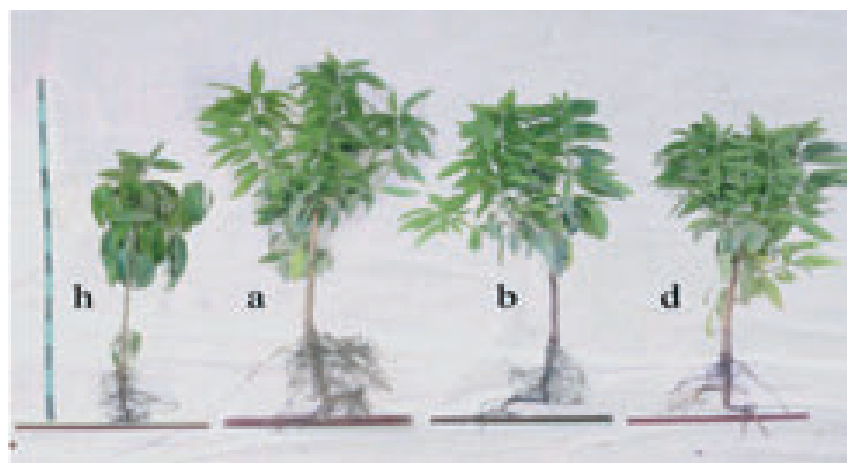

Photo (1). Refer to three and half years old of of Keit mango variety grafted on ( $h, a, b$, and d) which are Zebda, Socaria, 4/9 and 13-1 rootstocks, respectively

Table 2. Root parameter of the four tested rootstocks at the end of experiment in October 2007

\begin{tabular}{|c|c|c|c|c|c|}
\hline Rootstocks & $\begin{array}{c}\text { Number } \\
\text { of fibrous } \\
\text { roots }\end{array}$ & $\begin{array}{c}\text { Longest } \\
\text { horizon- } \\
\text { tical root } \\
\text { cm }\end{array}$ & $\begin{array}{c}\text { Longest } \\
\text { vertical } \\
\text { root cm }\end{array}$ & $\begin{array}{c}\text { Fresh } \\
\text { weight of } \\
\text { root } \\
\text { system } \\
\text { (kg) }\end{array}$ & $\begin{array}{c}\text { Dry } \\
\text { weight of } \\
\text { root } \\
\text { system } \\
\text { (kg) }\end{array}$ \\
\hline Zebda & $30.4 \mathrm{~b}$ & $15.5 \mathrm{c}$ & $23.5 \mathrm{~d}$ & $0.92 \mathrm{~d}$ & $0.380 \mathrm{~d}$ \\
\hline Socaria & $65.9 \mathrm{a}$ & $30.9 \mathrm{a}$ & $39 \mathrm{a}$ & $2.30 \mathrm{a}$ & $0.775 \mathrm{a}$ \\
\hline $13-1$ & $40.9 \mathrm{~b}$ & $22.3 \mathrm{~b}$ & $26 \mathrm{c}$ & $1.90 \mathrm{c}$ & $0.510 \mathrm{c}$ \\
\hline $4 / 9$ & $53.3 \mathrm{~b}$ & $25.3 \mathrm{~b}$ & $32.5 \mathrm{~b}$ & $1.93 \mathrm{~b}$ & $0.511 \mathrm{~b}$ \\
\hline
\end{tabular}

In Columns, the numbers which are followed by different characters means that there are significant differences

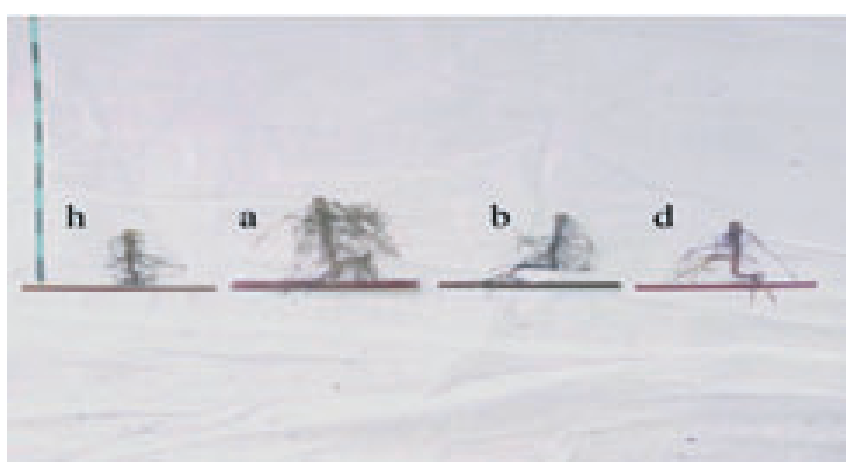

Photo (2). Refer to the root system of three and half years old Keit mango variety grafted on (h, a, b, and d) which are Zebda, Socaria, 4/9, 13-1 rootstocks, respectively

Table 3. Leaf nitrogen, phosphorous and potasium content (\%) of Keit mango variety as affected by grafting on the four mango rootstocks in 2006 and 2007 seasons.

\begin{tabular}{|c|c|c|c|}
\hline Rootstocks & N\% d.w & P\% d.w & K\% d.w \\
\hline \multicolumn{4}{|c|}{2006} \\
\hline Zebda & $1.60 \mathrm{c}$ & 0.130 & $0.81 \mathrm{~d}$ \\
\hline Socaria & $2.00 \mathrm{a}$ & 0.179 & $1.25 \mathrm{a}$ \\
\hline $13-1$ & $1.79 \mathrm{~b}$ & 0.165 & $1.04 \mathrm{c}$ \\
\hline $4 / 9$ & $1.80 \mathrm{~b}$ & 0.173 & 1. $13 \mathrm{~b}$ \\
\hline \multicolumn{4}{|c|}{2007} \\
\hline Zebda & $1.50 \mathrm{c}$ & 0.139 & $0.88 \mathrm{c}$ \\
\hline Socaria & $1.83 \mathrm{a}$ & 0.189 & $1.33 \mathrm{a}$ \\
\hline $13-1$ & $1.64 \mathrm{~b}$ & 0.158 & $1.13 \mathrm{~b}$ \\
\hline $4 / 9$ & $1.68 \mathrm{~b}$ & 0.179 & $1.29 \mathrm{a}$ \\
\hline
\end{tabular}

In Columns, the numbers which are followed by different characters means that there are significant differences

Table 4. Total carbohydrate content (\%) and Phenol content (mg/100g d.wt) in leaves of the Keit mango variety as affected by grafting on the four rootstocks in 2006 and 2007seasons.

\begin{tabular}{|c|c|c|}
\hline Rootstocks & $\mathrm{C}$ content $\%$ & Phenol content \\
\hline \multicolumn{3}{|c|}{2006} \\
\hline Zebda & $6.57 \mathrm{a}$ & $31.21 \mathrm{a}$ \\
\hline Socaria & $4.69 \mathrm{c}$ & $23.99 \mathrm{~d}$ \\
\hline $13-1$ & $5.88 \mathrm{~b}$ & $27.09 \mathrm{~b}$ \\
\hline $4 / 9$ & $4.71 \mathrm{c}$ & $24.99 \mathrm{c}$ \\
\hline \multicolumn{3}{|c|}{2007} \\
\hline Zebda & $7.503 \mathrm{a}$ & $12.02 \mathrm{a}$ \\
\hline Socaria & $5.94 \mathrm{c}$ & $11.92 \mathrm{~d}$ \\
\hline $13-1$ & $6.6 \mathrm{~b}$ & $12.34 \mathrm{~b}$ \\
\hline $4 / 9$ & $5.89 \mathrm{c}$ & $12.01 \mathrm{c}$ \\
\hline
\end{tabular}

In Columns, the numbers which are followed by different characters means that there are significant differences 


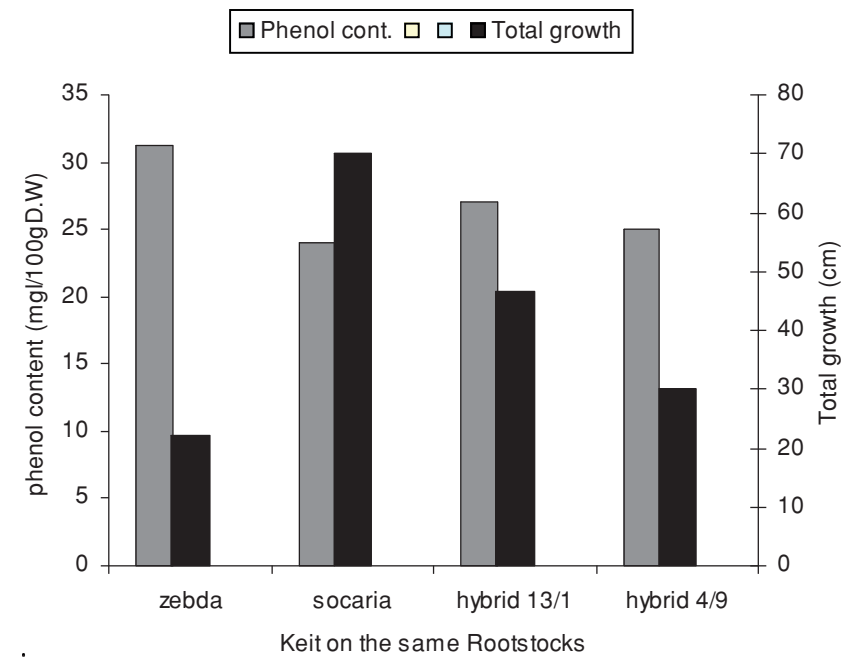

Fig 1. Relationship between total phenols content (mg/100g dry weight) and total growth of Keit mango as affected by grafting on tested rootstocks in 2006 season.

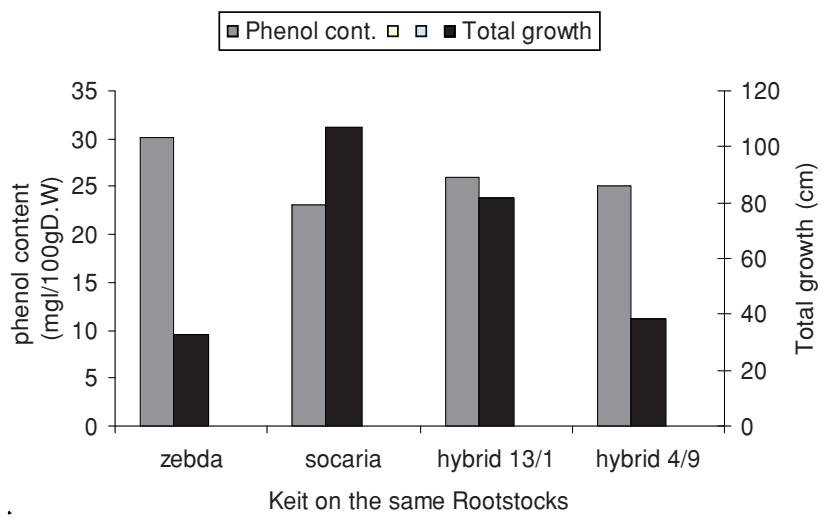

Fig 2. Relationship between total phenols content ( $\mathrm{mg} / 100 \mathrm{~g}$ dry weight) and total growth of Keit mango as affected by grafting on tested rootstocks in 2007 season

\section{References}

Azab, S.A. (1995): Studies on seven citrus rootstocks under the arid environment of Qatar 2-Leaf and root chemical constituents. Zagazig J. Agric. Rec. 22(5): 1315-1328.

Dubois, M., K. A. Glles, J.K. Hamilton, P. A. Rebers \& F. Smith (1956): Calorimetric method for determination of sugars and related substances. Analytical chemistry. 28 (3): 350-356.

Duran-zuazu, V.H. (2006): Fruit yield, plant growth and nutrient statues in mango as effect of rootstocks. Inter. J. F. Sci., 5 (4): 3-21.

El-Sayed, Somaia A. (2003a): Evaluating Volkamer lemon (C. Volkameriana) as rootstock for Valencia orange cultivar under Kafer El-Sheikh conditions. Mansoura, J. Agric. Res., 31 (5): 3025-3039.
Ennab, H.A. (2003): Evaluation study on Washington navels orange cultivar Budded on five rootstocks. Ph. D. Thesis, Fac. Agric., Tanta University.

Evenhuis, B. \& P.W. Dewaard (1980): Principles and practices in plant analysis. FAo Soil Bull. 38 (1): 152-163.

FAO production year book (2007): Food and Agricultural Organization of United Nations Room.

Hassan, M.M. (1994): Effect of citrus rootstocks on root distribution, tree growth and leaf mineral composition of Washington navel orange trees. Egypt J. Hort. 11 (2): 201-207.

Jackson, M.L. \& J.G. Brown ( 1955): A note on potentiometric determination of chloride. Proc. Amer. Sc. Hort. Sci., 65: 187,

Khattab. M.M., Guindy, L.F. \& Awad. N.A. (2001): A morpho Biochemical profile of three cilrus rootstoks seedling and their stianic continations of valencia orange (C. Sinensis Cl.) obeck. Egypt J. Hort. 26 (4): 413-430.

Kojima, K., T. Takahara, T. Ogeta \& N. Muramatsu (1995): Relationships between growth characteristics and endogenous ABA, IAA and GA

Kuriun, R.M., Reddy, V. P. \& Reddy, Y.T.N. (1996): Growth, yield, fruit quality and leaf nutrient status of thirteen your old 'Alphonse'.

Kuriun, R.M. \& C.P.A. Layer (1992): Stem anatomical characters in relation to tree vigour in mango (mangifora infical) Scienta Hort. 50(3/5): 245-253.

Murphy, J.P. \& J.D. Riely (1962): A modified single solution method for the determination of phosphate in Natural Water. Anol. Chem. Acta, 27: 31-36.

Murti, G.S.R. \& K.K. Upret (2003): Endogenous hormones and phemols in rootstock seedling of mango cultivars and ther relationship with seedling vigour. Europ. J. Hort. Sci., 68(1): 2-7.

Murti, G.S.R., K.K. Upreti, Y.T.N. Reddy \& Reju, M. Kurien (2000): Cytokinin and abscisic acid in xylem sap of mango CV. Aphonso grafted on rootstock of contrasting vigour. in dian J. Hort., 57(3): 221-223.

Nada, K., H. Okuda \& I. Iwaguki (2002): In dole acetic acid and abscises acid levels in new shoots and fibrous roots of citrus scionrootstock Combinations. Scientia Hort. 84 (314): 245-254.

Pregl, F. (1945): Quantitative Inorganic Microanalysis. 4th Ed. J. of A. Churchill, Ltd., London.

Rahtore, H.A., T. Massud, S. Sammi \& A.H. Soomro (2007): Effect of storage on physio-chemical composition and sensero properties of mango (mangifera indica L.) variety Daseharia. Pakstan j. nutrition. 6 (2): 143-148.

Reddy, Y.T.N. \& R.M. Kurian (2002): Leaf nutrient status of polyembryonic mango varieties and that of cv. Alphonso grafted on to some of these rootstocks. J. Appl. Hort., 2 (2): 106-107.

Sitaraimaiah, K. \& K. Pathak (1979): Effect of phenolics and aromatic acide on meoidogyre Javanica infecting tomato nematolgica, 25: 281-287. 